\title{
Limited risk of Zika virus transmission by five Aedes albopictus populations from Spain
}

\author{
Mikel A. González ${ }^{1,2}$, Márcio G. Pavan², Rosilainy S. Fernandes², Núria Busquets³, Mariana R. David², \\ Ricardo Lourenço-Oliveira ${ }^{2,4}$, Ana L. García-Pérez ${ }^{1}$ and Rafael Maciel-de-Freitas ${ }^{2,4^{*}}$ [D
}

\begin{abstract}
Background: Aedes albopictus, the Asian tiger mosquito, is an exotic invasive species in Europe. It has substantial public health relevance due to its potential role in transmitting several human pathogens. Out of the European countries, Spain has one of the highest risk levels of autochthonous arbovirus transmission due to both the high density of Ae. albopictus and the extensive tourist influx from vector-endemic areas. This study aims to investigate the susceptibility of five Ae. albopictus populations from mainland Spain and the Balearic Islands to a Brazilian Zika virus (ZIKV) strain.

Methods: The F1 generation of each Ae. albopictus population was orally challenged with a ZIKV-infected blood meal $\left(1.8 \times 10^{6} \mathrm{PFU} / \mathrm{ml}\right)$. At 7 and 14 days post-infection (dpi), mosquito bodies (thorax and abdomen) and heads were individually analysed through RT-qPCR to determine the infection rate (IR) and dissemination rate (DR), respectively. The saliva of infected mosquitoes was inoculated in Vero cells and the transmission rate was assessed by plaque assay or RT-qPCR on $\sim 33$ individuals per population.

Results: The IR and DR ranged between 12-88\%, and 0-60\%, respectively, suggesting that ZIKV is capable of crossing the midgut barrier. Remarkably, no infectious viral particle was found in saliva samples, indicating a low ability of ZIKV to overcome the salivary gland barrier. A subsequent assay revealed that a second non-infective blood meal $48 \mathrm{~h}$ after ZIKV exposure did not influence Ae. albopictus vector competence.

Conclusions: The oral experimental ZIKV infections performed here indicate that Ae. albopictus from Spain become infected and disseminate the virus through the body but has a limited ability to transmit the Brazilian ZIKV strain through biting. Therefore, the results suggest a limited risk of autochthonous ZIKV transmission in Spain by Ae. albopictus.
\end{abstract}

Keywords: Aedes albopictus, Zika virus, Spanish populations, Vector competence, Viral copies, RT-qPCR, Plaque assay

\section{Background}

Aedes albopictus (Diptera: Culicidae), also known as the Asian tiger mosquito, is ranked as one of the world's 100 most invasive species in the world [1]. This species has undergone a massive global expansion over recent decades facilitated by an effective network of air, ground and maritime human transportation, and the international

\footnotetext{
*Correspondence: freitas@ioc.fiocruz.br

${ }^{2}$ Laboratório de Mosquitos Transmissores de Hematozoários, Instituto Oswaldo Cruz, Fundação Oswaldo Cruz (IOC/ FIOCRUZ), Rio de Janeiro, Brazil

Full list of author information is available at the end of the article
}

trade of used tyres, lucky bamboo and flower pots, for instance [2]. So far, Ae. albopictus has been recorded in 27 European countries [3] since its introduction at the end of the 1970s in Albania [4]. A few years later, this species became established in Italy, and by late $1990 \mathrm{~s}$ reached France [5], making its arrival to Spain imminent at that time. Hence, in 2004, one larva in a tree hole and an adult male of Ae. albopictus were collected in the backyard of a house located near Barcelona [6]. In the following years, the presence of Ae. albopictus along the Mediterranean coast and Balearic Islands was also reported, with an upsurge in Catalonia and Valencia Autonomous Communities [7, 8]. 
The establishment of Ae. albopictus in Europe raises public health concerns since it is a competent vector of at least 26 arboviruses, including dengue (DENV), yellow fever (YFV), chikungunya (CHIKV) and Zika (ZIKV) viruses [9]. Imported cases of CHIKV and ZIKV have been reported in European countries infested by $A e$. albopictus, representing an alarming scenario that must not be overlooked [10,11]. The role of Ae. albopictus as a vector of ZIKV has been confirmed by vector competence assays and by the detection of naturally infected specimens [12].

Since 2016, the European Union has reported about 2340 ZIKV-confirmed cases. Spain is the second most affected country in the continent with 320 imported cases, half of them reported in Catalonia [13], one of the most likely port-of-entries for ZIKV in Europe due to its high touristic flow. Considering the high density of Ae. albopictus in Spain, especially in the Mediterranean region, it is essential to ascertain the vector competence of its local populations in order to estimate the potential risk of autochthonous ZIKV transmission.

In this study, we assessed the ability of five Spanish populations of Ae. albopictus to become infected, disseminate and transmit a Brazilian ZIKV strain. We also evaluated whether a second non-infected blood meal in previously ZIKV-exposed females would affect the viral load in mosquito tissues.

\section{Methods \\ Mosquito populations}

Eggs of five Ae. albopictus populations from the Iberian Peninsula and Balearic Islands, from Barcelona (BA), Valencia (VA), Palma de Mallorca (PM), Málaga (MA) and Guipúzcoa (GU) were collected with $\sim 12$ ovitraps/ locality placed on urban or peri-urban sites during the summer of 2017 (Fig. 1, Table 1).

Field-collected $F_{0}$ generation was reared to $F_{1}$ adult progeny to obtain enough mosquitoes to perform ZIKV oral infection experiments. Aedes albopictus females were fed twice per week on human blood (CAAE 53419815.9.0000.5248). Eggs were hatched, larvae were reared at a maximum density of $\approx 500$ individuals $/ 3$ 1 of water in plastic trays and fed daily with fish food (Tetramin, Tetra, Melle, Germany) until pupation. Pupae were transferred to $30 \times 30 \times 30 \mathrm{~cm}$ cages (BugDorms, Taichung, Taiwan) to allow adult emergence and mating. Colony mosquitoes were maintained in an insectary at $27 \pm 2{ }^{\circ} \mathrm{C}, 14: 10$ light:dark photoperiod, $>60 \%$ relative humidity and supplied with $15 \%$ sucrose diet ad libitum.

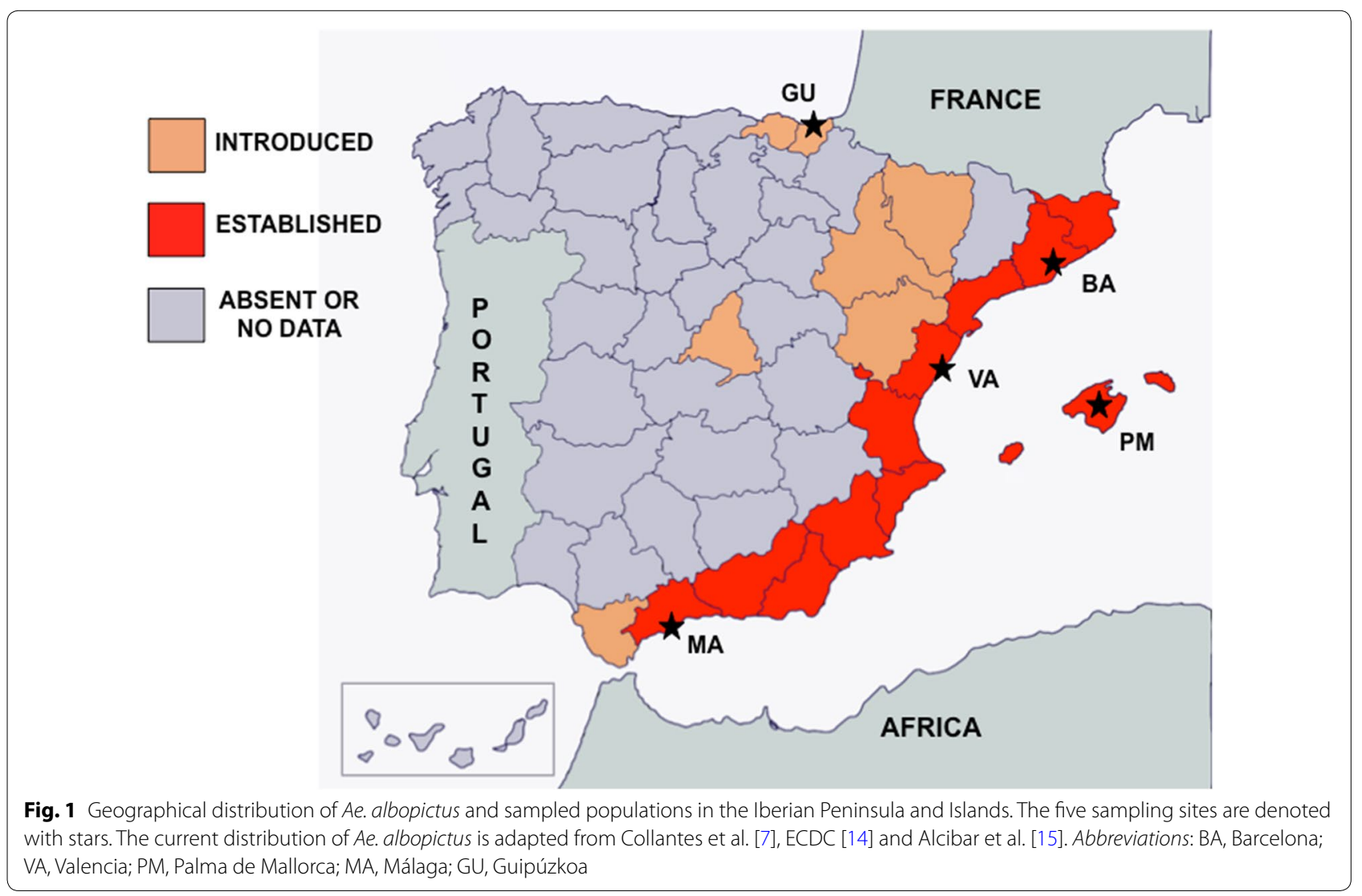


Table 1 Mosquito populations and field-collected eggs related information from Spanish mainland and Balearic Islands

\begin{tabular}{|c|c|c|c|c|c|}
\hline Mosquito population & Collection site & Current status in Spain ${ }^{\mathrm{a}}$ & $\begin{array}{l}\text { Total no. of } \\
\text { eggs }\end{array}$ & $\mathrm{OPI}^{\mathrm{c}}$ & $E D l^{d}$ \\
\hline Barcelona, Catalonia (BA) & $\left(41^{\circ} 48^{\prime} 33^{\prime \prime} \mathrm{N}, 2^{\circ} 03^{\prime} 33^{\prime \prime} \mathrm{E}\right)$ & Established for a long time & 500 & 88.8 & 96.4 \\
\hline Valencia, Valencian community (VA) & $\left(40^{\circ} 03^{\prime} 19^{\prime \prime} \mathrm{N}, 0^{\circ} 03^{\prime} 50^{\prime \prime} \mathrm{E}\right)$ & Established for a long time & 1300 & 77.7 & 185.8 \\
\hline Palma de Mallorca, Balearic Islands (PM) & $\left(39^{\circ} 41^{\prime} 45^{\prime \prime} \mathrm{N}, 2^{\circ} 42^{\prime} 0^{\prime \prime} \mathrm{E}\right)$ & Recently established & 760 & 83.3 & 76.1 \\
\hline Málaga, Andalusia (MA) & $\left(36^{\circ} 35^{\prime} 15^{\prime \prime} \mathrm{N}, 4^{\circ} 33^{\prime} 07^{\prime \prime} \mathrm{W}\right)$ & Recently established & 450 & 87.5 & 64.4 \\
\hline Guipúzcoa, Basque Country (GU) & $\left(43^{\circ} 20^{\prime} 35^{\prime \prime} \mathrm{N}, 1^{\circ} 45^{\prime} 44^{\prime \prime} \mathrm{W}\right)$ & Occasionally introduced & 54 & 4.1 & 9.1 \\
\hline
\end{tabular}

${ }^{a}$ Established for a long time ( $>7$ years) and recently established ( $<3$ years)

b Parental source of eggs $\left(\mathrm{F}_{0}\right)$

c Ovitrap Positive Index (OPI): frequency of positive ovitraps among the total examined

${ }^{d}$ Egg Density Index (EDI): no. of eggs / no. of positive ovitraps

\section{Virus strain}

The ZIKV strain (Asian lineage), namely ZIKV-PE243 (GenBank: KX197192), used in this study was isolated in 2015 from a patient from Recife, Pernambuco (northeast Brazil), [16] where a substantial increase of microcephaly cases in newborns was first detected in the Americas [17]. ZIKV was amplified in C6/36 mosquito cells (amplification step <10) maintained with Leibovitz's L15 medium (Sigma-Aldrich, Missouri, USA) supplemented with 2\% fetal bovine serum (FBS, Gibco, Invitrogen, USA), and incubated for 7 days at $28{ }^{\circ} \mathrm{C}$. Viral titers were quantified through a serial 10 -fold dilution via plaque-forming assay in Vero cells (Sigma Aldrich, St. Louis, MO, USA) prior to experimental infection, as reported by Fernandes et al. [18]. The virus sample contained $1.8 \times 10^{6} \mathrm{PFU} / \mathrm{ml}$ and was stored at $-80^{\circ} \mathrm{C}$ until use.

\section{Experiment 1: Vector competence of five Ae. albopictus populations from Spain}

At 5-6 days post-emergence, about 500 females of each population were divided in groups of 65 specimens and transferred to cardboard feeding boxes without access to sucrose solution. Oral infection experiments were performed after $24 \mathrm{~h}$ with 6-7 day-old female mosquitoes using a membrane feeding system (Hemotek, Great Harwood, UK), adapted with a pig-gut covering. The infective blood meal was offered in a proportion of $1 \mathrm{ml}$ of cell culture medium with virus to $2 \mathrm{ml}$ of rabbit erythrocytes. Mosquito experimental infection was done at a Biosafety Level-2 laboratory. Oral feeding was limited to $30 \mathrm{~min}$ and only fully engorged females were selected for vector competence assays. Mosquitoes were held in cylinder plastic cups at $27 \pm 0.5{ }^{\circ} \mathrm{C}, 12: 12 \mathrm{~h}$ light:dark cycle with high relative humidity $>70 \%$. Cotton balls with sucrose solution (15\%) were provided on the top of the cups and replaced daily.

We analyzed 25 specimens of each of the five populations by RT-qPCR at 7 and 14 days post-infection (dpi) to determine the infection rate (IR) and dissemination rate (DR). The transmission rate (TR) was estimated by both plaque assay of saliva of 25 individuals at 7 and 14 days post-infection (dpi) per population and by RTqPCR in 6-8 additional specimens per population at 14 dpi (Table 2).

Table 2 Summary of ZIKV vector competence experiments of Ae. albopictus populations from Spanish mainland and Balearic Islands

\begin{tabular}{|c|c|c|c|c|c|c|c|}
\hline \multirow{2}{*}{$\begin{array}{l}\text { Mosquito } \\
\text { population }\end{array}$} & \multirow{2}{*}{$\begin{array}{l}\text { No. of exposed } \\
\text { females }\end{array}$} & \multirow[t]{2}{*}{ Feeding rate (\%) } & \multirow{2}{*}{$\begin{array}{l}\text { Positive infected } \\
\text { females (\%) }\end{array}$} & \multicolumn{2}{|c|}{ Plaque assay ${ }^{a}$} & \multirow{2}{*}{$\begin{array}{l}\text { Total no. of samples } \\
\text { analysed }\end{array}$} & \multirow{2}{*}{$\begin{array}{l}\text { RT-PCR } \\
14 \mathrm{dpi}^{\mathrm{b}}\end{array}$} \\
\hline & & & & $7 \mathrm{dpi}$ & $14 \mathrm{dpi}$ & & \\
\hline BA & 500 & 52 & 88 & 25 & 25 & 150 & 8 \\
\hline VA & 480 & 23 & 68 & 25 & 25 & 150 & 8 \\
\hline PM & 392 & 26 & 24 & 25 & 25 & 150 & 6 \\
\hline MA & 390 & 39 & 32 & 25 & 25 & 150 & 6 \\
\hline GU & 442 & 39 & 84 & 25 & 25 & 150 & 8 \\
\hline
\end{tabular}

\footnotetext{
a Plaque assay $=25$ specimens per population ( 25 analysis of body, 25 analysis of head and 25 analysis of saliva) and condition

b Number of saliva samples analysed

Abbreviations: BA, Barcelona; VA, Valencia; PM, Palma de Mallorca; MA, Málaga; GU, Guipúzcoa
} 
Experiment 2: Effect of an additional uninfected blood meal on the Ae. albopictus vector competence to ZIKV ZIKV-infected 6-7 day-old females were separated into two groups: one-time blood-fed (1BF) and twice bloodfed (2BF). After $48 \mathrm{~h}$ (a proxy to simulate a second blood ingestion on a natural setting), 2BF females were fed with an additional uninfected rabbit blood meal. Only 10 females from BA and 10 from GU fed twice from a total of 152 females (60 and 92, respectively). BA and GU were selected as representatives of different introduction histories in Spain, with the former established for a long time and the latter occasionally introduced. The viral RNA loads and rates were compared between $1 \mathrm{BF}$ and 2BF groups at 7 days after the first blood meal by RT-qPCR.

\section{Sample processing and virus detection by RT-qPCR}

The head and body (thorax and abdomen) of the mosquitoes stored at $-80{ }^{\circ} \mathrm{C}$ were dissected on a chill-plate, and $250 \mu$ of Leibovitz's L15 medium supplemented with 4\% FBS was added to vials filled with 20-25 glass beads. Mosquito tissues were mechanically macerated using a rapid homogenizer (Precellys 24, Bertin Technologies, Montigny-le-Bretonneux, France) followed by centrifugation for $10 \mathrm{~min}$ at $10,000 \times \mathrm{rpm}$ and at $4{ }^{\circ} \mathrm{C}$. Suspended viral RNA was extracted from a $140 \mu \mathrm{l}$ volume using QIAamp Viral RNA Mini Kit (Qiagen, Dusseldorf, Germany) following manufacturer's instructions.

The one step RT-qPCR amplification (Superscript ${ }^{\text {TM }}$ III Platinum ${ }^{\mathrm{TM}}$, Invitrogen, Waltham, MA, USA) was performed as previously described [19] with some minor modifications. In brief, PCR reactions were performed using $13.5 \mu \mathrm{l}$ of master mix, $1.4 \mu \mathrm{l}(10 \mu \mathrm{M})$ of each primer (forward: 5'-CTT GGA GTG CTT GTG ATT-3'; and reverse: 5'-CTC CTC CAG TGT TCA TTT-3'), $0.4 \mu \mathrm{l}$ $(50 \mathrm{mM})$ of $\mathrm{MgSO}_{4}, 1.7 \mu \mathrm{l}(10 \mu \mathrm{M})$ TaqMan TAMRA probe (FAM 5'-AGA AGA GAA TGA CCA CAA AGA TCA-3' TAMRA), $0.4 \mu \mathrm{l}$ of Taq polymerase, $5 \mu \mathrm{l}$ of each RNA sample and $1.2 \mu \mathrm{l}$ of ultra-pure water to a final volume of $25 \mu \mathrm{l}$. Amplification reactions were performed in a QuantStudio 6 Flex Real-Time PCR System (Applied Biosystems, Foster City, CA, USA) programmed as follows: $45^{\circ} \mathrm{C}$ for $15 \mathrm{~min}$ and $95{ }^{\circ} \mathrm{C}$ for $2 \mathrm{~min}$, followed by 40 cycles of $95^{\circ} \mathrm{C}$ for $15 \mathrm{~s}, 58^{\circ} \mathrm{C}$ for $5 \mathrm{~s}$ and $60{ }^{\circ} \mathrm{C}$ for $30 \mathrm{~s}$.

\section{Collection of saliva and virus detection by plaque assay in Vero cells}

Female mosquitoes at 7 and $14 \mathrm{dpi}$ (Experiment 1) and at 7 dpi (Experiment 2) were immobilised on a Petri dish placed on ice and their legs and wings were removed with forceps. The proboscis of each live mosquito was inserted into a $10 \mu \mathrm{l}$ pipet tip containing $5 \mu \mathrm{l}$ of FBS and then expelled into a sterile $500 \mu \mathrm{l}$ microcentrifuge tube with $45 \mu \mathrm{l}$ of Leibovitz's L15 medium supplemented with penicillin $(10 \mu \mathrm{g} / \mathrm{ml})$, gentamicin $(1 \mu \mathrm{g} / \mathrm{ml})$ and fungizone $(1 \mu \mathrm{g} / \mathrm{ml})$. After $30 \mathrm{~min}$ of salivation, saliva samples and mosquito bodies were immediately stored at $-80^{\circ} \mathrm{C}$.

Vero cells were plated and incubated until monolayer formation. Then, the entire sample of the saliva $(50 \mu \mathrm{l})$ for each mosquito was placed on a 6-well plate containing the cells and incubated for $1 \mathrm{~h}\left(37^{\circ} \mathrm{C}, 5 \% \mathrm{CO}_{2}\right)$ and supplemented with Earle's 199 medium. After $1 \mathrm{~h}$ incubation, the supernatant was removed, and the cells were overlaid with carboxymethyl cellulose (CMC) in Earle's 199 medium. Inoculated Vero cells were incubated for 7 days and then fixed with $10 \%$ formaldehyde and stained with crystal violet $(0.02 \%)$. To ensure cell viability and to prevent self-contamination during the process, $50 \mu \mathrm{l}$ of 3-fold serial diluted ZIKV stock in Leibovitz's L15 medium was added in every assay to one of the plates as a positive control and cell culture medium alone as a negative control.

\section{Viral quantification and statistical analysis}

The number of ZIKV-RNA copies in the body and head was calculated with a ZIKV standard curve from 10-fold dilutions of known RNA copies $\left(10^{1}-10^{9}\right)$ included on every PCR plate. The limit of virus detection by RT-qPCR was established in five RNA copies. IR and DR were calculated as the proportion of females with infected bodies among the total tested and the proportion of females with infected heads among the total tested, respectively. TR refers to the total number of females with viral particles in saliva among the total tested. To ease comparison with previous papers in which different mosquito populations were challenged for ZIKV [18-22], we sought to replicate the experimental design and estimate IR, DR and TR in infected mosquitoes. Using the same ZIKV isolate described here, vector competence (demonstrated by the presence of ZIKV particles in mosquito heads) ranged from $86-100 \%$, highlighting good viral replication and the reliability of the techniques used for viral detection in varied tissues including mosquito saliva [21-23]. Fisher's exact test was applied to detect significant differences between proportions (IR and DR). The number of viral copies was compared using the non-parametric Kruskall-Wallis test followed by pairwise comparisons. Mann-Whitney U-test was used to compare the viral titres between 7 and $14 \mathrm{dpi}$ and between the groups of Experiment 2. Statistical analysis was performed with IBM SPSS statistics v.23.0.

\section{Results}

Indicators of Ae. albopictus infestation

A total 58 ovitraps were placed in the five regions from Spain (Table 1). Of these, $75 \%$ had at least one Ae. 
albopictus egg. The ovitrap positive index (OPI) ranged between $4-90 \%$ and the egg density index (EDI) ranged between 9-96 in July 2017. All geographical locations showed support for a high level of infestation by $A e$. albopictus mosquitoes, except for the GU population, which showed a low frequency of positive ovitraps and a reduced number of eggs (Table 1 ).

\section{Viral competence parameters}

In total, $38 \%$ of the females exposed to the infective blood meal were fully engorged (Table 2). Overall, the IR and DR increased at $14 \mathrm{dpi}$, except for the MA population for which a decrease was observed over time. Overall, the IR ranged from 39.2 to $55.2 \%$ and the DR varied from 13 to $36 \%$ at 7 and $14 \mathrm{dpi}$, respectively. A high level of heterogeneity was observed in the IR and DR among populations. BA, VA and GU populations showed superior permissiveness than $\mathrm{PM}$ and MA to ZIKV, with a higher DR at $7 \mathrm{dpi}$ (Chi-square test, $\left.X^{2}=13.8, d f=4, P=0.008\right)$ and IR and DR at $14 \mathrm{dpi}$ (IR: $\chi^{2}=48.8, d f=4, P \leq 0.001$ and DR: $\chi^{2}=31.7, d f=4$, $P \leq 0.001$ ) (Fig. 2a). On the other hand, mosquitoes from PM and MA presented low values of IR and DR. No ZIKV-disseminated infection was observed in $A e$. albopictus from VA at $7 \mathrm{dpi}$ and from MA at $14 \mathrm{dpi}$
(Fig. 2a). Remarkably, TR was zero for all populations as ZIKV particles were not detected in the saliva of any of the tested females by either plaque assay or RT-qPCR.

\section{Viral loads in mosquito tissues}

At $7 \mathrm{dpi}$, viral copies in bodies were similar among populations, but more ZIKV copies were found in mosquito bodies from BA, VA and GU than in mosquitoes from PM and MA at $14 \mathrm{dpi}$ (Kruskal-Wallis test, $\mathrm{W}=49.9, d f=4, P \leq 0.001$ ) (Fig. $2 \mathrm{~b}$ ). On the other hand, the number of ZIKV copies in the heads at $7 \mathrm{dpi}$ was not statistically different among populations. The number of viral copies in the body was heterogeneous at $14 \mathrm{dpi}$ and specimens from PM were found with less ZIKV copies in the body compared to the other populations (Kruskal-Wallis test, $\mathrm{W}=32.5, d f=4, P \leq 0.0001$ ) (Fig. 2b). Overall, the number of ZIKV copies had a 19-fold increase in infected heads (Mann-Whitney test, $U=1552.0, P=0.207)$ and 13 -fold in infected bodies $(U=216.0, P=0.038)$ from 7 to $14 \mathrm{dpi}$.

\section{Effect of a second blood meal on vector competence}

A second feeding on non-infected blood did not affect IR and DR (Mann-Whitney test, BA IR: $U=54.00, P=0.781$;

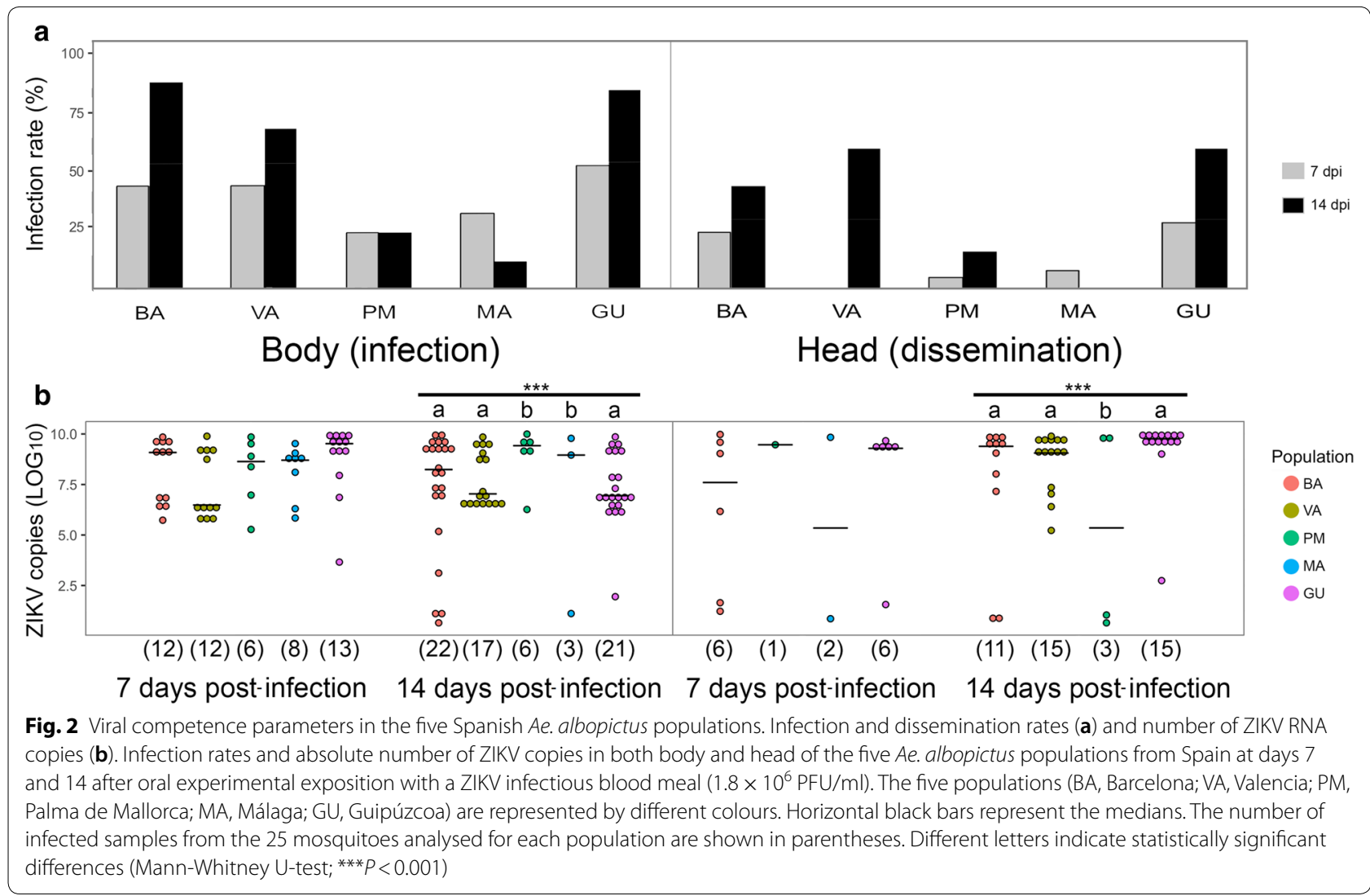


BA DR: $U=55.00, P=0.654$; GU IR: $U=42.50, P=0.293$; GU DR: $U=26.00, P=0.482)$ or number of viral copies (BA body: $U=46.00, P=0.796$; BA head: $U=45.00$, $P=0.739$; GU body: $U=44.50, P=0.684$; and GU head: $U=43.00, P=0.631$ ) (Fig. 3). Although not statistically significant, the mean ZIKV copies barely decreased in the BA population (1BF body: $2.3 \times 10^{5} \pm 1.3 \times 10^{5}$; $2 \mathrm{BF}$ body: $3.0 \times 10^{4} \pm 2.5 \times 10^{4}$; $1 \mathrm{BF}$ head: $78.4 \pm 76.7 ; 2 \mathrm{BF}$ head: $5.1 \pm 3.9$ for $2 \mathrm{BF}$ ), while the GU population exhibited an opposite outcome (1BF body: $8.7 \times 10^{5} \pm 7.0 \times 10^{5}$, $2 \mathrm{BF}$ body: $3.7 \times 10^{6} \pm 2.8 \times 10^{6}$; $1 \mathrm{BF}$ head: $34.4 \pm 29.6$; 2BF head: $\left.1.4 \times 10^{5} \pm 1.1 \times 10^{5}\right)$. Thus, an additional blood-feeding did not influence vector competence of Spanish Ae. albopictus to ZIKV.

\section{Discussion}

Vector competence is a key feature to determine the risk of pathogen transmission by mosquitoes. The success of a given mosquito population in transmitting a virus will depend on the ability of the virus to overcome both the midgut and salivary gland vector barriers [24]. Herein, we report the susceptibility of recently introduced and long-established Ae. albopictus populations from Spain to ZIKV. These five populations represent the current Ae. albopictus distribution in the country, portraying a nationwide sampling effort. Taken together, the results presented here suggested that this ZIKV strain is not transmitted during female blood-feeding due to the absence of infectious viral particles in Ae. albopictus saliva at 7 and $14 \mathrm{dpi}$.

Aedes albopictus has colonized the majority of the Spanish Mediterranean area since its arrival in 2004 [7] and its geographical distribution is still expanding with recent introductions in the Basque Country and Aragón [14]. According to the frequency of positive ovitraps and egg density retrieved from our data, the infestation index can be considered as high as in the regions where Ae. albopictus has been established for a long time or was recently introduced, which must concern public health managers. The exception is the Basque Country, where Ae. albopictus eggs were occasionally detected in restricted places near the border with France. In that particular case, public health authorities from the Basque Country must enhance vector surveillance and control on the border to avoid Ae. albopictus establishment.

The vector competence of Ae. albopictus to ZIKV has hitherto shown heterogeneous results, with the susceptibility status of field populations oscillating dramatically $[12,25,26]$. Our study has shown that Spanish Ae. albopictus populations are heterogeneously capable of becoming infected and disseminate ZIKV, but none were competent to transmit this virus strain through biting. The same ZIKV strain used herein showed high replication rates and was detected in Ae. aegypti saliva, demonstrating a high transmission rate [21, 22]. On the European scale, Ae. albopictus from France, Italy and Germany have demonstrated variable susceptibility to Asiatic ZIKV lineages [10, 27-29]. Our findings are aligned with those reported for Ae. albopictus populations from France and Italy [10, 29], which showed only few specimens with ZIKV in the saliva. Altogether, these results reinforce the hypothesis that Ae. albopictus from Mediterranean Europe might have limited vectorial capacity, at least for the ZIKV strain circulating in Brazil. Nonetheless, conclusions regarding the absence of ZIKV in Ae. albopictus saliva must be taken carefully for at least two reasons. First, forced salivation is a common method to diagnose arbovirus presence in saliva, but its collection is obtained after mosquitoes are immobilized with legs and wings removed. Therefore, the use of

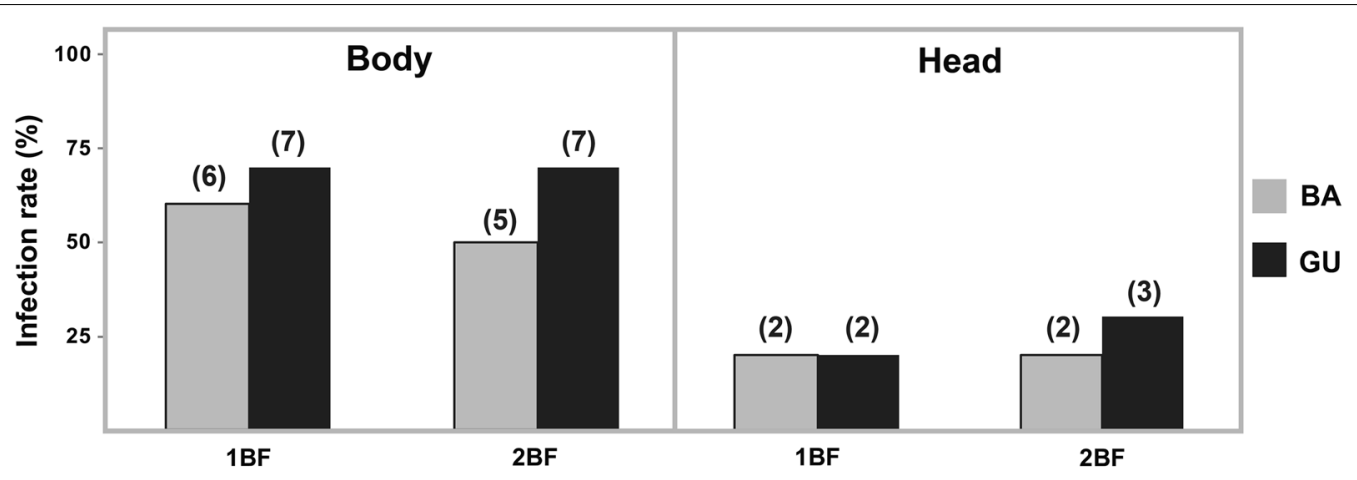

Fig. 3 Comparison of ZIKV infection rates of Ae. albopictus populations exposed or non-exposed to an additional ZIKV non-infective blood meal. Infection rates (body and head) at $7 \mathrm{dpi}$ of females that received a single ZIKV-infective blood meal (1BF) and those females fed on a second non-infective blood meal $48 \mathrm{~h}$ after viral exposure (2BF) are shown. Ten specimens were analysed for each condition. Populations: BA (Barcelona) and GU (Guipúzkoa). The numbers in parenthesis indicate the positive infected females 
non-sacrificial methods to collect saliva such as using a strip of filter paper, must be encouraged for vector competence studies [30]. Secondly, and most importantly, considering a mosquito species a negligible vector might produce undesired consequences such as the relaxation of vector control.

The viral concentration used in our study was slightly lower compared to other studies conducted with European populations of Ae. albopictus [10, 29], but with more viral particles than are naturally found in infected hosts [12]. In addition, environmental factors such as temperature may affect vector competence. For instance, the susceptibility of Ae. albopictus for CHIKV is affected depending on the incubation temperature of immature stages [31,32]. Moreover, our infection was conducted with fresh-wild populations (F1 generation), which might reflect better the vector competence of field populations [33].

Besides suitable environmental conditions, the establishment of an arbovirus transmission cycle depends on the genetic background of mosquito populations and the viral genotype [34, 35]. In Spain, two main hypotheses of Ae. albopictus introduction have been proposed, but not confirmed. The first is the dispersion along the entire Spanish Mediterranean coast including the Balearic Islands since their introduction and establishment in Barcelona. The second possible way of arrival is by occasional introductions from France to Guipúzkoa (northeast Spain) $[7,8]$. In this scenario, mosquitoes from the Guipúzkoa population may proceed from a nonestablished population, while the Barcelona and Valencia females might come from a long-established one. Despite that, GU, BA and VA exhibited higher IR and DR, whereas Palma de Mallorca and Málaga populations (collected in areas recently colonized by Ae. albopictus) showed an overall lower virus infection and dissemination. This lower vector competence could be explained by an impairment between mosquito and virus genotypes. The validation of this hypothesis depends on increasing the number of tested samples, future research on population genetics of these mosquitoes and assessing the vector competence of local Ae. albopictus for different strains of ZIKV but also other arboviruses. Until then, vector surveillance authorities must remain alert to produce a rapid response and effective vector control when suitable.

Aedes albopictus may feed on blood more than once in a single gonotrophic cycle [36]. Hence, understanding if repeated blood-feeding improves the viral load and infection rates is relevant from an epidemiological point of view, as the risk of arbovirus transmission might increase with repeated contact with hosts. Although the results of Experiment 2 were disparate between populations, it did not show statistically significant differences in viral copies after infected mosquitoes received a second non-infective blood meal. Aedes albopictus females from the PV population had a slightly increased viral load after the second blood meal, while the opposite was observed for BA. Amuzu et al. [37] evaluated the effect of multiple blood meals on dengue dynamics in Ae. aegypti and concluded that repeat feeding did not lead to an increase of IR or viral loads. Interestingly, a second non-infective blood meal shortened the extrinsic incubation period (EIP) of ZIKV-infected Ae. albopictus [38]. Our data did not support the increased percentage of mosquitoes observed by Armstrong et al. [38] who offered the second blood meal 4 days after ZIKV infection; in our study the second blood meal was offered only $48 \mathrm{~h}$ after infection. Bloodfeeding triggers mechanical and physiological changes in mosquitoes that could affect virus replication and thus the EIP. Therefore, it is possible that the effects of a second blood meal on virus replication is dependent on the time after infection it is offered to mosquitoes [39].

Furthermore, the vector potential of other species to transmit ZIKV in Spain should also be considered. The recently sporadic incursion of Ae. aegypti supported by maritime transport represents a recent rising concern in Spain. In December 2017, Ae. aegypti mosquitoes were reported in the Spanish outermost region of the Canary Islands, a popular destination for travellers [40]. Indeed, the new arrival and or/establishment of other exotic mosquito species of Aedes, i.e. Ae. japonicus, in a rural area of north Spain, suggests that the Spanish epidemic potential to arboviruses is dynamic and could change underlying the rapid global spread of invasive species [41].

\section{Conclusions}

The results from the oral experimental infections carried out in the present study suggest that Spanish Ae. albopictus populations are capable of becoming infected and disseminating ZIKV to other tissues. However, Ae. albopictus seems to have a limited ability for transmitting the ZIKV strain used herein since no viral particles were detected in saliva. Additional vector competence assays with other ZIKV strains must be conducted to increase the confidence of appointing Spanish Ae. albopictus as a non-competent vector.

\section{Abbreviations}

CHIKV: chikungunya virus; CMC: carboxymethyl cellulose; $C_{T}$ : cycle threshold; FBS: fetal bovine serum; DENV: dengue virus; dpi: days post-infection; DR: dissemination rate; EDI: egg density index; EIP: extrinsic incubation period; IR: infection rate; OPI: ovitrap positive index; PFU: plaque-forming unit; PCR: polymerase chain reaction; $R T-q P C R$ : reverse transcription $q P C R ; T R$ : transmission rate; YFV: yellow fever virus; ZIKV: Zika virus. 


\section{Acknowledgements}

The authors thank the entomologists who kindly donated tiger mosquito eggs from different parts of Spain: Mikel Bengoa, Javier Lucientes, Sarah Delacour, Francisco Collantes and Joseba Goikolea. We are also grateful to Fiocruz staff for technical support and laboratory assistance.

\section{Funding}

Funding was supported by FAPERJ E-26/201.335/2016. MAG receives a 3-year postdoctoral fellowship funded by the Basque Government. Coordenação de Aperfeiçoamento de Pessoal de Nível Superior (Grant No. 23038.007199/201217 and Finance Code 001).

\section{Availability of data and materials}

The data supporting the conclusions of this article are included within the article. Raw data are available from the corresponding author upon request. Samples are temporally stored at $-80^{\circ} \mathrm{C}$ in the Laboratório de Mosquitos Transmissores de Hematozoários (IOC/ FIOCRUZ).

\section{Authors' contributions}

Experimental conception and design: MGP, RLO and RMF. Vector competence experiments: MAG, MGP, RSF and MRD. Analysis and interpretation: MAG, MGP and RMF. Paper writing: MAG, RMF, RLO, NB and ALG. All authors read and approved the final manuscript.

\section{Ethics approval and consent to participate}

Mosquito blood-feeding was performed with human blood obtained from anonymous donors from the blood bank of the Rio de Janeiro State University, whose blood bags would have been discarded due to small volume. We have no information on donors, including sex, age and clinical condition. The use of human blood was approved by the Fiocruz Ethical Committee (CAAE 53419815.9.0000.5248)

\section{Consent for publication}

Not applicable.

\section{Competing interests}

The authors declare that they have no competing interests.

\section{Publisher's Note}

Springer Nature remains neutral with regard to jurisdictional claims in published maps and institutional affiliations.

\begin{abstract}
Author details
${ }^{1}$ NEIKER-Instituto Vasco de Investigación y Desarrollo Agrario, Derio, Bizkaia, Spain. ${ }^{2}$ Laboratório de Mosquitos Transmissores de Hematozoários, Instituto Oswaldo Cruz, Fundação Oswaldo Cruz (IOC/ FIOCRUZ), Rio de Janeiro, Brazil. ${ }^{3}$ IRTA, Centre de Recerca en Sanitat Animal (CReSA, IRTA-UAB), Campus de la Universitat Autònoma de Barcelona, Bellaterra, Spain. ${ }^{4}$ Instituto Nacional de Ciência e Tecnologia em Entomologia Molecular, Universidade Federal do Rio de Janeiro, Rio de Janeiro, Brazil.
\end{abstract}

Received: 15 October 2018 Accepted: 26 February 2019

Published online: 29 March 2019

\section{References}

1. Bonizzoni M, Gasperi G, Chen XJA. The invasive mosquito species Aedes albopictus: current knowledge and future perspectives. Trends Parasitol. 2014;29:460-8

2. Medlock JM, Hansford KM, Schaffner F, Versteirt V, Hendrickx G, Zeller $\mathrm{H}$, et al. A review of the invasive mosquitoes in Europe: ecology, public health risks, and control options. Vector Borne Zoonotic Dis. 2012:12:435-47.

3. Medlock JM, Vaux AGC, Cull B, Schaffner F, Gillingham E, Pfluger V, Leach S. Detection of the invasive mosquito species Aedes albopictus in southern England. Lancet Infect Dis. 2017;17:140.

4. Adhami JRP. Introduction and establishment of Aedes (Stegomyia) albopictus Skuse (Diptera: Culicidae) in Albania. J Am Mosq Control Assoc. 1998:14:340-3.
5. Schaffner F, Karch S. Premiere observation d'Aedes albopictus (Skuse, 1894) en France metropolitaine. Compt Rend Academie Sci Ser III. 2000:323:373-5.

6. Aranda C, Eritja R, Roiz D. First record and establishment of the mosquito Aedes albopictus in Spain. Med Vet Entomol. 2006;20:150-2.

7. Collantes F, Delacour S, Delgado JA, Bengoa M, Torrell-Sorio A, Guinea H, et al. Updating the known distribution of Aedes albopictus (Skuse, 1894) in Spain 2015. Acta Trop. 2016;164:64-8.

8. Eritja R, Palmer JRB, Roiz D, Sanpera-Calbet I, Bartumeus F. Direct evidence of adult Aedes albopictus dispersal by car. Sci Rep. 2017;7:14399.

9. Paupy C, Delatte H, Bagny L, Corbel V, Fontenille D. Aedes albopictus, an arbovirus vector: from the darkness to the light. Microbes Infect. 2009;11:1177-85.

10. Jupille H, Seixas G, Mousson L, Sousa CA, Failloux AB. Zika virus, a new threat for Europe? PLoS Negl Trop Dis. 2016;10:e0004901.

11. Marano G, Pupella S, Pati I, Masiello F, Franchini M, Vaglio S, et al. Ten years since the last chikungunya virus outbreak in Italy: history repeats itself. Blood Transfus. 2017:15:489-90.

12. Epelboin $Y$, Talaga S, Epelboin L, Dusfour I. Zika virus: an updated review of competent or naturally infected mosquitoes. PLoS Negl Trop Dis. 2017;11:e0005933.

13. ECDC. European Centre for Disease Prevetion and Control. Zika transmission; 2018. https://ecdc.europa.eu/en/zika-virus-infection/threats-andoutbreaks/zika-transmission. Accessed 10 July 2018.

14. ECDC. European Centre for Disease Prevetion and Control. Aedes albopictus - current known distribution in Europe; 2018. https://ecdc.europ a.eu/en/disease-vectors/surveillance-and-disease-data/mosquito-maps. Accessed 10 July 2018.

15. Alcibar RM, Tello A, Marino Hernando E, Vázquez Martinez MA. Aedes (Stegomyia) albopictus (Skuse, 1894) (Diptera, Culicidae) primera cita para la Comunidad de Madrid, España. Boln Asoc Esp Ent. 2017:41:3-4 (In Spanish).

16. Faria NR, Azevedo RDSDS, Kraemer MUG, Souza R, Cunha MS, Hill SC, et al Zika virus in the Americas: early epidemiological and genetic findings. Science. 2016;352:345-9.

17. Lowe R, Barcellos C, Brasil P, Cruz OG, Honório NA, Kuper H, et al. The Zika virus epidemic in Brazil: from discovery to future implications. Int J Environ Res Public Health. 2018;15:E96.

18. Fernandes RS, Campos SS, Ferreira-de-Brito A, Miranda MR, Silva KAB, Gonçalves MC, et al. Culex quinquefasciatus from Rio de Janeiro is not competent to transmit the local Zika virus. PLoS Negl Trop Dis. 2016:10:e0004993.

19. Ferreira-de-Brito A, Ribeiro RM, Miranda RM, Fernandes RS, Campos SS, Silva KA, et al. First detection of natural infection of Aedes aegypti with Zika virus in Brazil and throughout South America. Mem Inst Oswaldo Cruz. 2016;111:655-8.

20. Chouin-Carneiro T, Vega-Rua A, Vazeille M, Yebakima A, Girod R, Goindin $D$, et al. Differential susceptibilities of Aedes aegypti and Aedes albopictus from the Americas to Zika virus. PLoS Negl Trop Dis. 2016;10:e0004543.

21. Fernandes RS, Campos SS, Ribeiro OS, Raphael LM, Bonaldo MC, Lourenço-de-Oliveira R. Culex quinquefasciatus from areas with the highest incidence of microcephaly associated with Zika virus infections in the Northeast Region of Brazil are refractory to the virus. Mem Inst Oswaldo Cruz. 2017;112:577-9.

22. Dutra HLC, Rocha MN, Dias FBS, Mansur SB, Caragata EP, Moreira LA. Wolbachia blocks currently circulating Zika virus isolates in Brazilian Aedes aegypti. Cell Host Microbe. 2016;19:771-4.

23. Petersen MT, Silveira ID, Tatila-Ferreira A, David MR, Chouin-Carneiro T, Van den Wouwer $L$, et al. The impact of the age of first blood meal and Zika virus infection on Aedes aegypti egg production and longevity. PLoS One. 2018;13:e0200766.

24. Vogels CBF, Göertz GP, Pijlman GP, Koenraadt CJM. Vector competence of European mosquitoes for west Nile virus. Emerg Microbes Infect. 2017:6:e96.

25. Kauffman EB, Kramer LD. Zika virus mosquito vectors: competence, biology, and vector control. J Infect Dis. 2017;216(Suppl. 10):S976-90.

26. Boyer S, Calvez E, Chouin-Carneiro T, Diallo D, Failloux AB. An overview of mosquito vectors of Zika virus. Microbes Infect. 2018;20:646-60.

27. Ryckebusch F, Berthet M, Missé D, Choumet V. Infection of a French population of Aedes albopictus and of Aedes aegypti (Paea strain) with Zika 
virus reveals low transmission rates to these vectors' saliva. Int J Mol Sci. 2017;18:E2384.

28. Heitmann A, Jansen S, Lühken R, Leggewie M, Badusche M, Pluskota B, et al. Experimental transmission of Zika virus by mosquitoes from central Europe. Euro Surveill. 2017;22:30437.

29. Di Luca M, Severini F, Toma L, Boccolini D, Romi R, Remoli ME, et al. Experimental studies of susceptibility of Italian Aedes albopictus to Zika virus. Euro Surveill. 2016;21:30223.

30. Lequime S, Richard V, Cao-Lorneau VM, Lambrechts L. Full-genome dengue virus sequencing in mosquito saliva shows lack of convergent positive selection during transmission by Aedes aegypti. Virus Evol. 2017;3:vex031.

31. Westbrook CJ, Reiskind MH, Pesko KN, Greene KE, Lounibos LP. Larval environmental temperature and the susceptibility of Aedes albopictus Skuse (Diptera: Culicidae) to chikungunya virus. Vector Borne Zoonotic Dis. 2010;10:241-7.

32. Zouache K, Fontaine A, Vega-Rua A, Mousson L, Thiberge JM, LourencoDe-Oliveira $\mathrm{R}$, et al. Three-way interactions between mosquito population, viral strain and temperature underlying chikungunya virus transmission potential. Proc Biol Sci. 2014;281:20141078.

33. Weger-Lucarelli J, Rückert C, Chotiwan N, Nguyen C, Garcia Luna SM, Fauver JR, et al. Vector competence of American mosquitoes for three strains of Zika virus. PLoS Negl Trop Dis. 2016;10:e0005101.

34. Ciota AT, Bialosuknia SM, Zink SD, Brecher M, Ehrbar DJ, Morrissette MN, et al. Effects of Zika virus strain and Aedes mosquito species on vector competence. Emerg Infect Dis. 2017;23:1110-7.
35. Azar SR, Roundy CM, Rossi SL, Huang JH, Leal G, Yun R, Fernandez-Salas I, et al. Differential vector competency of Aedes albopictus populations from the Americas for Zika virus. Am Soc Trop Med Hyg. 2017;97:330-9.

36. Farjana T, Tuno N. Multiple blood feeding and host-seeking behavior in Aedes aegypti and Aedes albopictus (Diptera: Culicidae). J Med Entomol. 2013;50:838-46.

37. Amuzu HE, Simmons CP, McGraw EA. Effect of repeat human blood feeding on Wolbachia density and dengue virus infection in Aedes aegypti. Parasit Vectors. 2015;8:246.

38. Armstrong PM, Ehrlich H, Bransfield A, Warren JL, Pitzer VE, Brackney DE. Successive bloodmeals enhance virus dissemination within mosquitoes and increase transmission potencial. BioRxiv. 2018. https://doi. org/10.1101/246306.

39. Dong S, Balaraman V, Kantor AM, Lin J, Grant DG, Held NL, et al. Chikungunya virus dissemination from the midgut of Aedes aegypti is associated with temporal basal lamina degradation during bloodmeal digestion. PLoS Negl Trop Dis. 2017;11:e0005976.

40. European Centre for Disease Prevention and Control. New settlements of Aedes aegypti raising concerns for continental EU; 2018. https://ecdc. europa.eu/en/news-events/new-settlements-aedes-aegypti-raisingconcerns-continental-eu. Accessed 07 Jan 2019.

41. Juliano SA, Lounibos LP. Ecology of invasive mosquitoes: effects on resident species and on human health. Ecol Lett. 2005;8:558-74.
Ready to submit your research? Choose BMC and benefit from:

- fast, convenient online submission

- thorough peer review by experienced researchers in your field

- rapid publication on acceptance

- support for research data, including large and complex data types

- gold Open Access which fosters wider collaboration and increased citations

- maximum visibility for your research: over $100 \mathrm{M}$ website views per year

At BMC, research is always in progress.

Learn more biomedcentral.com/submissions 